\title{
Student Teachers' Attitude and Self-esteem towards Online Learning: Application of Rasch Measurement Model
}

\author{
Mohd Rustam Mohd Rameli, Najua Syuhada Ahmad Alhassora*, Muhammad Abd Hadi Bunyamin, \\ Chuzairy Hanri
}

School of Education, Faculty of Social Sciences and Humanities, Universiti Teknologi Malaysia (UTM), Malaysia

Received June 24, 2020; Revised September 12, 2020; Accepted November 7, 2020

\section{Cite This Paper in the following Citation Styles}

(a): [1] Mohd Rustam Mohd Rameli, Najua Syuhada Ahmad Alhassora, Muhammad Abd Hadi Bunyamin, Chuzairy Hanri , "Student Teachers' Attitude and Self-esteem towards Online Learning: Application of Rasch Measurement Model," Universal Journal of Educational Research, Vol. 8, No. 11C, pp. 37 - 44, 2020. DOI: 10.13189/ujer.2020.082305.

(b): Mohd Rustam Mohd Rameli, Najua Syuhada Ahmad Alhassora, Muhammad Abd Hadi Bunyamin, Chuzairy Hanri (2020). Student Teachers' Attitude and Self-esteem towards Online Learning: Application of Rasch Measurement Model. Universal Journal of Educational Research, 8(11C), 37- 44. DOI: 10.13189/ujer.2020.082305.

Copyright $\odot 2020$ by authors, all rights reserved. Authors agree that this article remains permanently open access under the terms of the Creative Commons Attribution License 4.0 International License

\begin{abstract}
The spread of the COVID-19 epidemic has changed the education delivery system. Educators are encouraged to continue the online teaching process to ensure that students can continue to learn whereby a program or course which is designed intentionally to be carried out fully online through some platforms that include Skype, Zoom, Google meet, Webex, and Kahoot. Thus, there is a need in conducting a study to identify the attitude and self-esteem towards online learning especially among student teachers. Therefore, this study aims to investigate student teachers' attitude towards online learning, student's teacher's self-esteem towards online learning and also the relationship between attitude and self-esteem towards online learning among student teachers. A total of 143 student teachers who undergo their teaching practicum are involved in this study. There are two instruments used in this study which are self-develop (Questionnaire measuring Attitude) and adopted instrument from the Rosenberg Self-Esteem Inventory (RSES). All the collected data were analysed by using Rasch Measurement Model. Based on the result, the student's teachers show better attitude in the aspect of cognitive but negative attitude in the aspect of affective and behaviour. Meanwhile, the overall student teachers have moderate level of self-esteem. Findings showed that the self-esteem was significantly positive and moderately
\end{abstract}

related with attitude towards the correlation coefficient .500. In conclusion, attitude and self-esteem are the important aspect for an educator in order to maintain a good teaching and effective learning process to the students even in facing an emergency situation.

Keywords Student Teachers, Attitude, Self-esteem, Online Learning

\section{Background of Study}

The spring of the COVID-19 outbreak has changed education dramatically, with the distinctive rise of online learning, in which learning and teaching are undertaken on digital platforms, which is among the physical distancing policies to help slow down the transmission of the coronavirus disease and ease burden for the health systems. With the sudden shift away from the classrooms in most parts of the globe, the online form of learning is whereby a program or course which is designed intentionally to be carried out fully online through some platforms that include Skype, Zoom, Google meet, Webex, Microsoft teams, Slack, and Kahoot (Tseng, Cheng \& Yeh, 2019; Zhang \& Qin, 2018). Online learning encompasses some 
variety of study, coursework and learning which is facilitated or conducted via the internet usage and some electronic gadgets such as the computer or phone whereby the students and the educator are staying separately in different venues which supplement the normal class learning (Lubis, Ritonga, Hia \& Nasution, 2020; Nachimuthu, 2020).

The rise of the global pandemic forced a bump into online courses and learning plans for student teachers and educators, where their attitude toward the online learning is a powerful influencer for the online learning behaviour and becomes a great thing of concern (Mulenga \& Marban, 2020). Student teacher's attitude is concerned with their way of thinking, behaving and acting which has a serious effect on the learner, which is developed in consequence of their experience toward online learning. To optimise the online learning, student teachers require the right infrastructure and support which will boost a good attitude toward the online learning which contributes to a positive self- esteem toward online learning. Without these, the online learning will be wasteful (Bao, 2020). For those who are capable and have the capital as well as the resources can utilize the online platforms for learning, but for those who are unable are further deprived (Zhong et al., 2020). This will eventually lead the way to more division among the privileged and fewer privilege individuals.

Concerning online learning therefore, the student teacher's self-esteem is an important variable that plays a crucial role in an individual behaviour which enables students to be positive and have a self-assurance toward online learning. A powerful sense of self-esteem aggrandizes human personal well-being and accomplishments in many ways (Bandura, 1998). According to a psychologist Albert Bandura in Adalsteinsson, Frimannsdottir and Konradsson, (2014), self-esteem is seen as the personal judgment of how well an individual can perform a course of action required to deal with some prospective situations. This involves perseverance and determination to overcome any difficulty that can interfere with utilizing the innate abilities to be achieved (Gulsen, 2017). Due to coronavirus pandemic and the rapid change of learning styles from the traditional to online learning, high self-esteem trends among student teachers will support their autonomy and confidence. Student teachers with high self-esteem will probably determine the appropriate course of action to enhance and support their online learning outcomes independently other than the students with a low self-esteem (Prior, Mazanov, Meacheam, Heaslip \& Hanson, 2016). Having a good self-esteem toward online learning will motivate, guide and support the student teachers learning processes. With the self-directed approach, the students are expected to succeed and have a goal-satisfying approach in executing the online learning tasks which include downloading/ uploading learning materials, contributing to the discussion boards, viewing documents and also enhances their self-directed online learning.

Based on the above-mentioned issues, this study aims to investigate student teachers' attitude towards online learning, student's teacher's self-esteem towards online learning and also the relationship between attitude and self-esteem towards online learning among student teachers.

\section{Methodology}

This quantitative approach research study specifically employed correlational research design. A total of 143 student teachers who were undergoing their teaching practice under the supervision of certified teachers and also monitored by university lecturer involved as the sample of this study. A set of questionnaires serve as the measuring tools for this study. Student teachers' attitude was measured through 12 items which was developed based on the ABC model of attitude. Each of the subconstructs of attitude (Affective, Behavior and Cognitive) was measure through 4 items respectively. Meanwhile, the 10 items on self-esteem were adopted from the Rosenberg Self-Esteem Inventory (RSES).

Rasch measurement model was applied to measure the level of student teachers' attitude and self-esteem. The distribution of all items was analysed based on the measure value, and person-item map. Item with low measure value (placed lower in the person-item map) implies that the particular item is easier to be executed by the sample and vice versa (Figure 1). Meanwhile, spearman rho correlation analysis was applied to identify whether there is significant relationship between student teachers' attitude and self-esteem. 


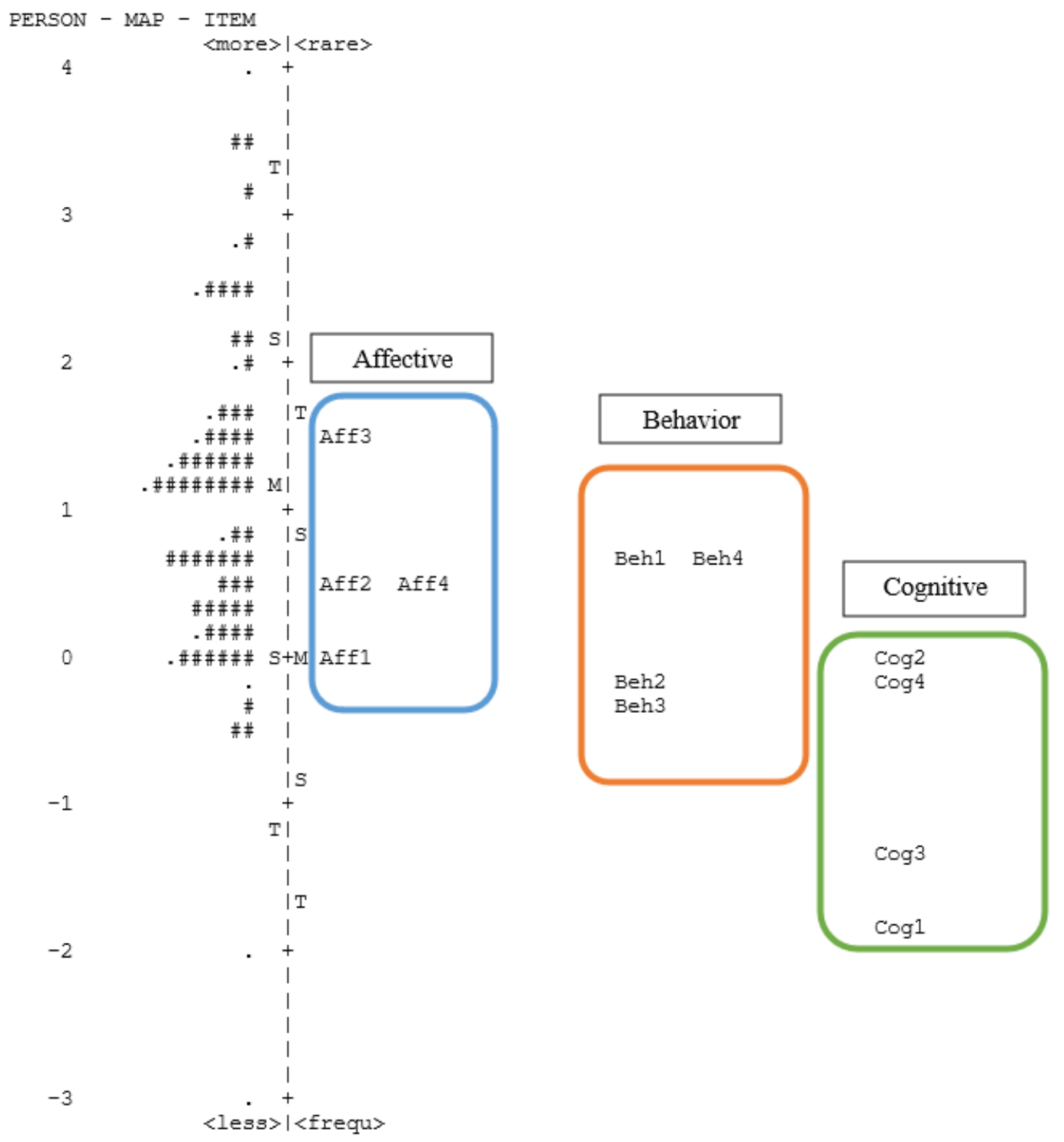

Figure 1. Person-Item Map for Student Teachers’ Attitude

\section{Results}

Table 1 shows the measure value, average measure and rank for the three subconstructs of attitude. For the subconstruct affective, three of the items showed a positive measure value. Specifically, one of the items is more than 1 measure value (A3) which indicated that respondents feels that online teaching is less viable than conventional learning. Meanwhile, among the four items on this subconstructs, item A1 showed a negative measure value (measure $=-0.08$ ). This implies that respondents have a confident feeling in making mistakes in giving instruction through online platform. Overall, the average measure for affective subconstruct is 0.63 at moderate level. 
Table 1. Measure Value for Student Teachers' Attitude

\begin{tabular}{|c|c|c|}
\hline Subconstructs & $\begin{array}{l}\text { Measure } \\
\text { Value }\end{array}$ & Rank (Level) \\
\hline \multicolumn{3}{|l|}{ Affective } \\
\hline $\begin{array}{l}\text { A1: I am not afraid of making mistakes in giving students online instructions because it is part of the } \\
\text { learning process }\end{array}$ & -0.08 & \multirow{4}{*}{$\begin{array}{c}\text { Average } \\
\text { Measure: } 0.63 \\
\\
\text { Rank } 3 \\
\text { (Moderate) }\end{array}$} \\
\hline A2: I feel confident about using online platforms for teaching & .56 & \\
\hline A3: I feel online teaching is a viable learning approach compared to conventional learning & 1.44 & \\
\hline A4: I feel that online teaching offers the possibility to efficiently manage my time & .58 & \\
\hline \multicolumn{3}{|l|}{ Behaviour } \\
\hline B1: I will use online teaching platforms regularly when teaching students & .71 & \multirow{4}{*}{$\begin{array}{c}\text { Average } \\
\text { Measure: } 0.23 \\
\text { Rank } 2 \\
\text { (Moderate) }\end{array}$} \\
\hline B2: I will use online teaching platforms that offers many functions to support teaching and learning & -.18 & \\
\hline $\begin{array}{l}\text { B3: I will adapt online communication techniques through various online networks because it is a fun way } \\
\text { to communicate with my students }\end{array}$ & -.31 & \\
\hline B4: I will transition into online teaching methods as it assures schedule flexibility & .71 & \\
\hline \multicolumn{3}{|l|}{ Cognitive } \\
\hline C1: I believe that using online systems requires a lot of mental effort & -1.90 & \multirow{4}{*}{$\begin{array}{l}\text { Average } \\
\text { Measure: -0.86 } \\
\text { Rank 1 } \\
\text { (High) }\end{array}$} \\
\hline $\begin{array}{l}\text { C2: I believe that the time commitment for developing distance education courses is comparable to those in } \\
\text { face-to-face classes }\end{array}$ & -0.08 & \\
\hline C3: I believe that online learning enhances my teaching experience & -1.28 & \\
\hline C4: I believe that online learning will improve the quality of knowledge attained & -0.17 & \\
\hline
\end{tabular}

For the subconstruct behaviour, both two of the items showed a positive and negative measure value respectively. Based on the measure value for item B2 and B3, respondents are willing to use online teaching platforms (measure $=-0.18$, high level) and adapt online communication techniques (measure $=-0.31$, high level). However, result for B1 and B4 showed a moderate measure value (.71) which indicated that respondents still not willing to use online platform regularly and make transitions into online teaching method.

For the last subconstruct of attitude which is cognitive, all the items showed negative value. Results indicated that respondents believe that online learning could enhance their teaching experiences (C3: measure=-1.28) and will improve the quality of knowledge attained (C4: measure $=-0.17$ ). However, item C1 showed the lowest measure value $(-1.90)$ which implies that respondents strongly believe that using online systems requires lots of mental effort.

For the variable self-esteem, the measuring items could be classified into three main levels as illustrated in Figure 2 and Table 2. Item SE2 showed the highest measure value (1.07) which means majority of respondents disagree with this item (low level of self-esteem). Meanwhile, 5 items classified as moderate level of self-esteem with measure value range from .11-.83. Lastly, 4 items fall under high measure value which majority of respondents agree with these items (value range: $-0.48-1.21$ ). 


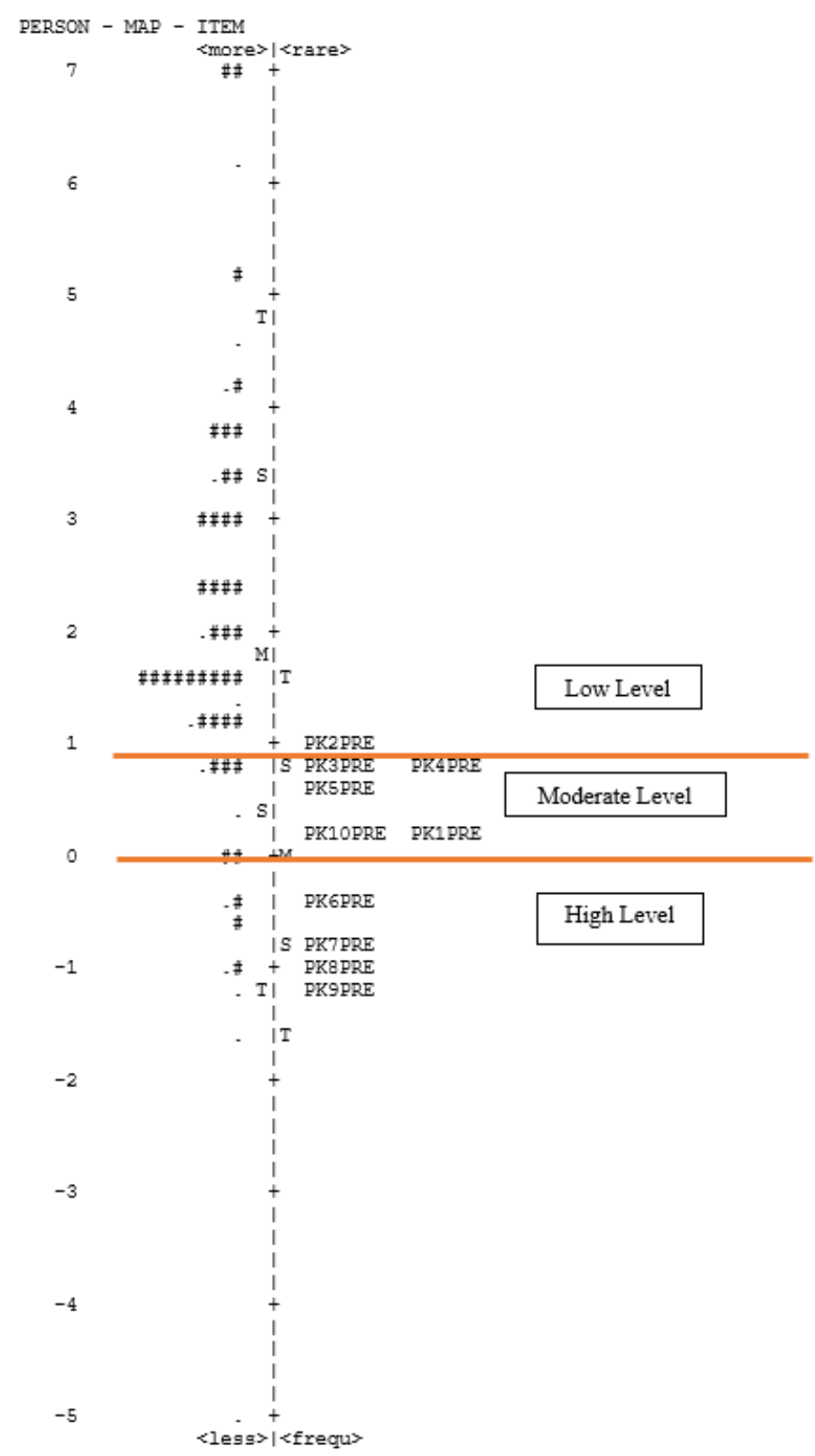

Figure 2. Person-Item Map for Student Teachers’ Self-esteem

Table 2. Measure Value for Student Teachers' Attitude

\begin{tabular}{|l|c|c|}
\hline \multicolumn{1}{|c|}{ Subconstructs } & Measure Value & Level \\
\hline (In the context of online teaching and learning) & & \\
\hline SE2: I think I am great person as a whole & 1.07 & Low \\
\hline SE3: I feel that I have a number of good qualities & .83 & .71 \\
\hline SE4: I am able to do things as well as most other people & .57 & \multirow{2}{*}{ Moderate } \\
\hline SE5: I am proud of myself and my achievements & .29 & \\
\hline SE1: On the whole, I am satisfied with myself & .11 & \\
\hline SE10: All in all, I am inclined to feel that I am a successful person & -.48 & \multirow{2}{*}{ High } \\
\hline SE6: I feel that I bring a certain value to the society & -.82 & -1.07 \\
\hline SE7: I feel that I am person of worth, at least on an equal plane with others & -1.21 & \\
\hline SE8: I am able to practice self-respect & & \\
\hline SE9: I take a positive attitude toward myself & & \\
\hline
\end{tabular}


Spearman Rho correlation analysis was done to identify the inter correlation between the Self-esteem with attitude in implementing online learning. Findings in the Table 3 showed that the self-esteem was significantly positive and moderately related with attitude with the correlation coefficient .500 .

Table 3. Correlational Analysis between Student Teachers' Attitude and Self-esteem

\begin{tabular}{|c|c|c|c|c|}
\hline & & & Attitude & Self-esteem \\
\hline \multirow{6}{*}{$\begin{array}{l}\text { Spearman's } \\
\text { rho }\end{array}$} & \multirow{3}{*}{ Attitude } & $\begin{array}{l}\text { Correlation } \\
\text { Coefficient }\end{array}$ & 1.000 & $.500^{* *}$ \\
\hline & & Sig. (2-tailed) & . & .000 \\
\hline & & $\mathrm{N}$ & 143 & 143 \\
\hline & \multirow{3}{*}{ Self-Esteem } & $\begin{array}{l}\text { Correlation } \\
\text { Coefficient }\end{array}$ & $.500^{* *}$ & 1.000 \\
\hline & & Sig. (2-tailed) & .000 & . \\
\hline & & $\mathrm{N}$ & 143 & 143 \\
\hline \multicolumn{3}{|c|}{$\begin{array}{l}\text { **. Correlation is significant at the } 0.01 \\
\text { level ( } 2 \text {-tailed). }\end{array}$} & & \\
\hline
\end{tabular}

\section{Discussion on Student Teachers' Attitude and Self-esteem towards Online Learning}

Student teachers' success toward online learning entirely depends on their attitudes towards online learning activities. Attitude toward online learning plays an important role in the processes of online learning among the student. Attitude is a variable that is usually concerned with students' perception about the online learning, their way of thinking, acting and behaving which affects the learner, the teacher and the immediate mingling group of the learner, which are developed as a result of the student experience in learning (Mumford \& Dikilitas, 2020). Therefore, findings of the present study indicate that the affective subconstruct has a moderate measure of 0.63 , behaviour subconstruct also show a moderate measure of 0.23 while the cognitive subconstruct recorded a high measure of 0.86 respectively. The student-teachers' attitudes toward online learning are explained based on the ABC model, which states that the structure of attitude is described with the consideration of three components (Affect, Behavior and Cognitive); these three components assist the researcher in measuring the attitude aspects comprising of the student teachers self-confidence in their ability toward online learning, perception of the importance of online learning and enjoyment of the online courses. However, by examining the three specific components of the ABC Model of attitude, the acquired results will contribute to the existing literature by providing data on each of the model components.

Rasch analysis has been applied to determine the measure for each subconstruct. The first subconstruct is labelled "Affective" which is an emotional component measuring student teachers feeling and emotions that are associated with their attitude toward online learning, this encompasses their self-confidence and enjoyment toward the online causes (Chatterjee \& Correia, 2020). The affective subconstruct indicates a moderate level of affective in attitude among the student teachers. This implies that respondents have a confident feeling in making mistakes in giving instruction through online platforms. Students experience and skills in using technologies are among the factors that can influence the student teacher's perspectives and attitude toward distance and online learning (Birbal, Ramdass \& Harripaul, 2018). Lack of skill is another element that can result in technological barriers which will lead to demotivation and weaker intentions toward online learning as well as their confidence. on the other hand, good skills in working with digital technologies will pave a way to a positive attitude towards online learning (Salloum, Alhamad, Al-Emran, Monem \& Shaalan, 2019).

The second subconstruct is labelled "behaviour", it comprises all kind of actions which are displayed by the learner's attitude toward online learning, and it shows the extent to which the student teachers can or cannot excellently perform online giving tasks. For the behaviour subconstruct, two of the items showed a positive measure which includes item B2 and B3 which indicate that the respondents are ready to accept the use of online teaching. This goes together with the findings of Mulenga and Marban (2020) which shows students have good skills toward the online learning platforms. However, results for B1 and B4 showed a moderate measure value which shows how respondents are not willing to participate in online learning regularly. The present study is also in line with the study of Nachimuthu (2020), stated that if a negative attitude is exhibited toward the online learning, it can lead to developing frequent uninterested online learning session. According to Zhong et al., (2020), online learning can be less reliable than the traditional learning style in terms of collaborative activities assessment and peer feedback.

The third subconstruct is labelled "cognitive" it is an aspect that deals with the knowledge and information the student teachers can know about their ability toward online learning as well as its usefulness. All the four items on the cognitive component show a negative value, which implies that the respondents have confidence and believe that online learning can augment their experience in teaching and learning on the online platforms and they believe the online courses required a lot of mental effort. This finding is in support of the work by Prior, Mazanov, Meacheam, Heaslip and Hanson (2016) where it was found a positive attitude among students toward online learning. Cognitive encompass some processes that involve thinking or memory and it is a section that store and organizes information for an individual (Garrison \& Cleveland-Innes, 2005). If student teachers have a strong cognitive belief, 
they can perform successfully the online task and despite the high cognitive belief, a student behaviour toward online courses can be less positive.

Online learning has been intensified in order to support learners' learning processes. Online learning self-esteem is an influential factor that enhances academic performance which has become an important element of success in learning and teaching activities, and this involves the student's judgements of their abilities in organizing and executing a course of action required in order to achieve a designated type of performances (Khalid, 2019). The findings of the present study based on the constructs of self-esteem in the context of online teaching and learning are divided into three, some of the items show a high level, some show a moderate level and some are showing a low level of self-esteem among the student teachers. There are some issues to an individual degree of self-esteem which is associated with successful adaptation to different learning styles, self-control, ability to accept criticism and positive emotions. Consequently, an individual with positive thoughts about himself toward learning online his self-esteem is high; if thoughts about oneself is negative then self-esteem will become low (Sungur, 2015).

For the variable self-esteem, Item SE2 showed the highest measure value which means the majority of respondents disagree with this item and it indicates a low level of self-esteem. Meanwhile, 5 items show a moderate level of self-esteem among student teachers. This indicates that in one way or another the respondents are sometimes not confident enough with the online courses. Adalsteinsson, Frimannsdottir and Konradsson (2014) stated that low self-esteem related to online teaching and learning can lead to undesirable adaptation of the online courses and different kind of cognitive problems which include lack of self-confidence, lack of motivation and afraid to express different Ideas or opinion on the online platforms. 4 items fall under high measure value which the majority of respondents are showing confidence and agree with the item contents. Individuals with high self-esteem make an effort to become successful in their endeavours, as assessed by others and themselves. The category of individuals showing high self-esteem toward the online courses focuses themselves on their strengths to be exceptionally good toward online platforms (Yokoyama, 2019).

\section{Discussion on Relationship between Student Teachers' Attitude and Self-esteem towards Online Learning}

Spearman Rho correlation analysis was conducted for this study in order to determine the relationship between the total scores of Self-esteem and attitude in implementing online learning. Spearman Rho correlation for the findings of this study indicate a positive significant relationship which is moderately related between attitude and self-esteem with a correlation coefficient of .500 and a significance level of .000 . Based on the results obtained from the study, the result acquired is a proof providing evidence on the existence of a relationship between attitude and self-esteem. It is assumed that a teacher with high self-esteem will likely develop a positive attitude toward online learning (Wasserman \& Migdal, 2019). The influence of correlating attitude and self-esteem can be related to a previous study by Kim, Hong and Song (2019). They explained that high self-esteem can be correlated positively with student's attitude toward online learning because self-esteem is directly related to the learner's feelings of autonomy, high motivation level and the ability to self-regulate the online learning process which is important in the online learning environment. Due to the coronavirus pandemic, the integration of technology into the educational system is the most effective and efficient way of providing distance education in order to do away with the spread of the virus (Kucharski et al., 2020).

Spearman Rho correlation result shows that the strength of the correlation between attitude and self-esteem is at a medium level. This could be because the previous study shows that other factors can correlate with the student teacher's attitude. In a study by Peytcheva-Forsyth, Yovkova and Aleksieva (2018), they explained that lack of experience in working with a variety of ICT in a specific educational context and deficiency in using technologies in the everyday life can be some of the variables that can influence the attitude of individuals toward learning online. Possibly, high self-esteem may lead to a positive attitude towards online teaching because Nwoye, Akpom and Hwang (2019) explain that student's attitude is the actual measure of behaviour intensions and the intensions are the factors that pilot an individual to develop a positive or negative attitude (Chatterjee \& Correia, 2020).

\section{REFERENCES}

[1] Adalsteinsson, R. I., Frimannsdottir, I. B., \& Konradsson, S. (2014). Teachers' Self-esteem and Self-efficacy. Scandinavian Journal of Educational Research, 58(5), 540 550. https://doi.org/10.1080/00313831.2013.773559

[2] Bandura, A. (1998). Encyclopedia of mental health. In Encyclopedia of human behavior (Vol. 4, pp. 71-81). https://doi.org/10.5860/choice.36-0036

[3] Bao, W. (2020). Covid -19 and Online Teaching in Higher Education: A Case Study of Peking University. Human Behavior and Emerging Technologies, 2(2), 113-115. https://doi.org/10.1002/hbe2.191

[4] Birbal, R., Ramdass, M., \& Harripaul, C. (2018). Student Teachers' Attitudes Towards Blended Learning. Journal of Education and Human Development, 7(2), 9-26. https://doi.org/10.15640/jehd.v7n2a2 
[5] Chatterjee, R., \& Correia, A. P. (2020). Online Students' Attitudes Toward Collaborative Learning and Sense of Community. American Journal of Distance Education, 34(1), 53-68. https://doi.org/10.1080/08923647.2020.1703 479

[6] Garrison, R. D., \& Cleveland-Innes, M. (2005). Facilitating Cognitive Presence in Online Learning: Interaction Is Not Enough. International Journal of Phytoremediation, 21(1), 133-148. https://doi.org/10.1207/s15389286ajde1903_2

[7] Gülșen Büyükşahin Çevik (2017). The Roles of Life Satisfaction, Teaching Efficacy, and Self-esteem in Predicting Teachers' Job Satisfaction. Universal Journal of Educational Research, 5(3), 338 - 346. DOI: 10.13189/ujer.2017.050306.

[8] Khalid, F. (2019). Students’ Identities and its Relationships with their Engagement in an Online Learning Commnity. International Journal of Emerging Technologies in Learning, 14(5), 4-19. https://doi.org/10.3991/ijet.v14i05.8 196

[9] Kim, H. J., Hong, A. J., \& Song, H. D. (2019). The roles of academic engagement and digital readiness in students' achievements in university e-learning environments. International Journal of Educational Technology in Higher Education, 16(1). https://doi.org/10.1186/s41239-019-0152 $-3$

[10] Kucharski, A. J., Russell, T. W., Diamond, C., Liu, Y., Edmunds, J., Funk, S., \& Eggo, R. M. (2020). Early Dynamics of Transmission and Control of COVID-19: A Mathematical Modelling Study. The Lancet Infectious Diseases, 20(5), 553-558. https://doi.org/10.1016/S1473-30 99(20)30144-4

[11] Lubis, A., Ritonga, A., Hia, Y., \& Nasution, A. A. (2020). Online Learning Design at Higher Education: An Example from Mathematics Classroom. Journal of Physics: Conference Series, 1462(1). https://doi.org/10.1088/1742-6 596/1462/1/012004

[12] Mumford, S., \& Dikilitaş, K. (2020). Pre-service Language Teachers Reflection Development Through Online Interaction in a Hybrid Learning Course. Computers and Education, 144 (September 2019), 1-13. https://doi.org/10. 1016/j.compedu.2019.103706

[13] Mulenga, E. M., \& Marban, J. M. (2020). Prospective Teachers' Online Learning Mathematics Activities in the Age of COVID-19: A Cluster Analysis Approach. Eurasia Journal of Mathematics, Science and Technology Education, 16(9), 1-9. https://doi.org/10.29333/ejmste/8345
[14] Nachimuthu, K. (2020). Student Teacher's Attitude Towards Online Learning During Covid-19. International Journal of Advanced Science and Technology, 29(6), 8745-8749.

[15] Peytcheva-Forsyth, R., Yovkova, B., \& Aleksieva, L. (2018). Factors Affecting Students' Attitudes Towards Online Learning - The Case of Sofia University. AIP Conference Proceedings, (December), 1-9. https://doi.org/10.1063/1.50 82043

[16] Prior, D. D., Mazanov, J., Meacheam, D., Heaslip, G., \& Hanson, J. (2016). Attitude, Digital Literacy and Self Efficacy: Flow-On Effects for Online Learning Behavior. Internet and Higher Education, 29, 91-97. https://doi.org/10.1016/j.iheduc.2016.01.001

[17] Salloum, S. A., Alhamad, Q. M., Al-Emran, M., Monem, A. A., \& Shaalan, K. (2019). Exploring Students' Acceptance of E-learning Through the Development of a Comprehensive Technology Acceptance Model. IEEE Access, 7, 128445128462. https://doi.org/10.1109/ACCESS.2019.2939467

[18] Sungur, G. (2015). The Effect of Online Self-Esteem and Awareness Training Program on University Students. Procedia - Social and Behavioral Sciences, 197(February), 476-481. https://doi.org/10.1016/j.sbspro.2015.07.171

[19] Tseng, J. J., Cheng, Y. S., \& Yeh, H. N. (2019). How Pre-service English Teachers Enact TPACK in the context of Web-conferencing Teaching: A Design Thinking Approach. Computers and Education, 128(September 2018), 171-182. https://doi.org/10.1016/j.compedu.2018.09.022

[20] Wasserman, E., \& Migdal, R. (2019). Professional Development: Teachers' Attitudes in Inline and Traditional Training Courses. Online Learning Journal, 23(1), 132-143. https://doi.org/10.24059/olj.v23i1.1299

[21] Yokoyama, S. (2019). Academic Self-Efficacy and Academic Performance in Online Learning. Eucational Psychology, (January), 373-378.

[22] Zhang, W., \& Qin, S. (2018). A Brief Analysis of the key Technologies and Applications of Educational Data Mining on Online Learning Platform. 2018 IEEE 3rd International Conference on Big Data Analysis, ICBDA 2018, 83-86. https://doi.org/10.1109/ICBDA.2018.8367655

[23] Zhong, B.-L., Luo, W., Li, H.-M., Zhang, Q.-Q., Liu, X. G., \& Li, W.-T. (2020). Knowledge, Attitudes, and Practices Towards Covid-19 Among Chinese Residents During the Rapid Rise Period of the Covid-19 Outbreak: A Quick Online Cross-Sectional Survey. International Journal of Biological Sciences, 16(10), 1745-1752. https://doi.org/10. $7150 /$ ijbs. 45221 